\section{Višnja Samardžija, Hrvoje Butković (eds.) FROM THE LISBON STRATEGY TO EUROPE 2020}

Institute for International Relations (IMO), Zagreb, 2010, $312 \mathrm{pp}$.

The book From the Lisbon Strategy to Europe 2020 was issued by the Institute for International Relations (IMO) with the support of the Delegation of the European Union in Croatia. It is written in English accompanied by executive summaries in Croatian, and also offers a bilingual glossary at the end. It represents an analytical outcome of the IMO's long-term research activities within the project "Lisbon Strategy - the Catalyst of Reforms in the EU and Croatia" supported by the Ministry of Science, Education and Sports. The book comprises works of researchers from IMO, Faculty of Law at the University of Zagreb and Institute of Economics, while foreign contributions are represented by scholars from the Corvinus University in Budapest and the University of Ljubljana. The book evaluates achievements and shortcomings of the Lisbon Strategy implementation as the main EU development agenda in the previous decade and analyzes perspectives of the new strategy Europe 2020 that sets foundation for the future EU paradigm of "smart, sustainable and inclusive growth". Particular emphasis is given to the experiences and challenges of the new EU member states that can present a valuable source of policy-learning for Croatia because EU po- licy-domains and the Lisbon-driven reforms are also analyzed with regard to the current situation and challenges in Croatia, thus offering concrete recommendations and measures to be undertaken. The book's basic aim is to merge expertise on setting priorities and objectives of the Lisbon Strategy's implementation methodologies, assess challenges of the new Europe 2020 strategy and analyze overall relevance of these strategies for Croatia. Indeed, it is particularly important in Croatia to raise awareness on the importance of effective implementation of Lisbon-type reforms that are an indispensable prerequisite for efficient EU membership. The book also aims to transfer knowledge to the EU candidate countries because these reforms secure greater policy-convergence with the EU and higher economic growth that positively influences their EU accession path. The publication is divided into two parts; the first part is devoted to the overall strategic perspectives of the Lisbon and Europe 2020 strategies, it evaluates development, achievements and shortcomings of the Lisbon Strategy and elaborates perspectives and challenges of the Europe 2020 strategy. The second part is focused on thematic issues as it assesses sectoral fields, where the authors analyze particular policy domains in the context of the Lisbon Strategy, their future development within the Europe 2020 Strategy and evaluate implementation in the EU member states in these areas with particular reference to the situation in Croatia.

The first part of the book consists of three contributions that start with the analysis of the Lisbon Strategy's development, adaptations and influence on EU policy-making, composed by Hrvoje Butković and Višnja Samardžija. The strategy represented an ambitious reform agenda launched in March 2000 with the goal to raise the EU's competitiveness and boost economic growth in the knowledge-based economy challenged by the United States and Japan. Its programme integrated economic, social and later an environmental policy as a tenet of innovation-driven and sustainable growth. Therefore, the Lisbon 
DRUŠ. ISTRAŽ. ZAGREB

GOD. 20 (2011)

RECENZIJE I PRIKAZI

BR. 2 (1 112$)$

STR. 583-599

Strategy encompassed the entire EU policy-making arena because it included issues central to growth such as internal market, entrepreneurship, fiscal consolidation and research capacity but it also embraced employment, social and environmental protection policies. However, despite delivering mixed success after its decade, the Lisbon Strategy has fundamentally influenced EU policy-making and governance because it enabled greater policy convergence and the exchange of best practices between member states, thus becoming an important catalyst of reforms in the EU. Also, it paved the way for the continuation of the EU development agenda, now enshrined in the Europe 2020 strategy that continues with the Lisbon-type reforms but develops innovative elements in order to upgrade its governance dimension, whose weaknesses were revealed during the economic crisis. Thereby, Europe 2020 initiates stronger macro-economic and fiscal surveillance and thematic coordination on structural reforms that aim to strengthen the EU's economic governance. The strategy also puts greater emphasis on the implementation through greater coherence and better collaboration between the national and the EU level and aims to prove its external relevance as well. Namely, Europe 2020 now explicitly mentions its importance for the EU candidate, potential candidate and neighbouring countries which are expected to be more closely associated with this agenda. In this way, Europe 2020 can become a leverage for reforms for the non-EU members and secure their greater policy convergence.

This extension of the EU governance and upgrading of its global profile has particularly been analyzed by Atilla Ágh. He claims that the Lisbon Strategy merged internal and external policy profiles of the
EU, thus contributing to the shaping of global governance with particular emphasis on the EU's neighbouring regions, a task that will be even more emphasized within the Europe 2020 strategy. In his analysis, the Lisbon decade resulted in the creation of the EU's strategic policy-planning and policy coordination that caused synergic effects and qualitatively enhanced EU governance. Regarding the perspectives of the Europe 2020 strategy, its success fundamentally depends on the new EU institutional architecture enshrined in the Lisbon Treaty because this new EU metagovernance structure represents an indispensable framework for its efficient implementation. This means that the Lisbon Treaty should enable integrated decision-making at the EU's top level and further merge Community and national levels because those are prerequisites for the success of the new EU development strategy. Finally, Europe 2020 strongly endorses the idea of "social productivity", which actually means integrating competitiveness and cohesion, because this secures the EU's consolidated posture on the global scene, also in line with the Lisbon Treaty that emphasizes economic, social and territorial cohesion. In addition, Mojmir Mrak recommends concrete proposals that aim to enhance the implementation of the new post-Lisbon strategy. Namely, the Open Method of Coordination (OMC), as the Lisbon Strategy's principal implementation method, has not created enough reform incentives among member states due to its "soft-law" nature. Therefore, Mrak suggests that the post-Lisbon strategy has to be underpinned by the improved governance mechanisms both at the EU and the national level with the aim to upgrade political ownership of the strategy and amend its implementation's methodology. This means greater political ownership over National Reforms Programmes (NRP) at the domestic level and their better evaluation by the Commission with a special surveillance of structural reforms. Moreover, this perceives an upgraded position of the Council that should have greater political ownership over the post-Lisbon strategy at the EU level. 
DRUŠ. ISTRAŽ. ZAGREB

GOD. 20 (2011)

RECENZIJE

I PRIKAZI

STR. 583-599

The second part of the book comprises seven contributions and starts with Krešimir Jurlin's focus on competitiveness and education. Competitiveness strategically lies at the heart of both the Lisbon and Europe 2020 strategies because it is a precondition for sustainable economic growth, high employment and social cohesion. He focuses on two areas that are particularly important for competitiveness, namely regulative environment and education and training. A regulatory environment conducive for investment, innovation and entrepreneurship is a necessary prerequisite for business dynamics and competitiveness. Therefore, the EU aims to reduce its regulatory burden by $25 \%$ until 2012, improve existing and new regulations and facilitate funding for the start-ups and small and medium enterprises (SMEs) in order to enhance their innovation capacity. Education and training are also pillars of competitiveness, so the major goal is to modernize higher education and enhance employability of the working force. The author analyzes achievements of the EU member states and assesses Croatia's competitiveness and the challenges it faces. Giorgia Demarchi analyzes the research and development policy (R\&D) that is central to the sustainable and competitive knowledge-based society and economy. The Lisbon decade upgraded its profile on the policy agenda with a strong emphasis on the knowledge triangle of education, research and innovation and "fifth freedom", freedom of knowledge. However, research and innovation policies also depend upon the wider economic and legal environment. Therefore, the author analyzes the importance of increased private R\&D expenditures, strengthened capacity for innovation and better university-industry ties. She elaborates the main achievements in the EU in this field composed by the creation of innovation clusters and strengthening of research cooperation throughout European Research Area (ERA) or Seventh Framework Programme (FP7) and focuses on Croatia's position related to the research and innovation policy. The competition policy is analyzed by Ivona Ondelj, a domain that witnessed considerable improvements within the Lisbon Strategy with the introduction of better prevention techniques and sanctioning mechanisms, especially in the field of state aid. Therefore, Europe 2020 , with its strong focus on anti-protectionist behavior, further services liberalization and creation of a better business and consumer environment offers a good basis for policy improvements aimed to tackle market distortions. She also analyzes competition policy developments in Romania and Bulgaria and concludes with the remaining challenges that Croatia faces prior to EU accession.

Paul Stubbs and Siniša Zrinščak have focused on the social dimension of the Lisbon and Europe 2020 strategies. Social policy has predominantly remained in the national policy domains determined by the subsidiarity principle, so the OMC's impact has been limited. Nevertheless, due to the impacts of the crisis and flaws of its predecessor, Europe 2020 now articulates a stronger social dimension as it aims to reduce the total number of people threatened by poverty by 20 million and it launches a European platform against poverty. It also emphasizes responsibilities of the EU member states to shape programs for threatened social groups and use EU funds for social innovation. Finally, the authors analyze the Europeanization of social policy in the new EU member states and Croatia. Hrvoje Butković and Igor Vidačak deal with social economy, a relatively new phenomenon that apart from indirect has concrete economic benefits due to its hybrid nature that is both social and market-driven. Therefore, the EU has recognized it as a developmental factor and included it in its policy-making. Although this topic has not been appropriately included in the Lisbon Strategy, the Europe 2020 strategy 
DRUŠ. ISTRAŽ. ZAGREB

GOD. 20 (2011)

RECENZIJE I PRIKAZI

BR. 2 ( 1112$)$,

STR. 583-599

could give it greater value because of its enhanced social dimension. The authors have also evaluated perspectives of greater affirmation for social economy in Croatia.

The energy goals of the Lisbon Strategy are analyzed by Ana-Maria Boromisa, whose targets of achieving competitiveness, sustainability and security of energy supply are inherited by Europe 2020 as well. Nevertheless, these achievements are hindered by the often conflictual nature and trade-offs between these goals and member states' reluctance to allow liberalization of the energy market sector. Regarding Croatia's energy policy, it is shaped by national development goals, the EU integration process and the EU energy policy itself. Finally, the environmental dimension of the EU development strategies is given by Sanja Tišma and Helena Cermak. They indicated that the 6th Environmental Action Programme launched in 2001 became the basis for the development of the Lisbon Strategy's environmental branch. The environmental dimension represents a constituent part of the new Europe 2020 strategy with its emphasis on "green growth", where it serves as a platform for increased innovation, productivity and employment. However, the success of environmental goals in the future period will depend on their policy integration in other areas and better cooperation among different stakeholders. The authors also evaluate compliance with the EU environmental acquis among the new EU member states, which can serve as a good basis for Croatia's implementation of the EU environmental protection policy.

Launching of the Europe 2020 strategy as the new EU development agenda represents perfect momentum for the eva- luation of the Lisbon decade and perspectives of the new strategy. Therefore, the book represents a valuable contribution to the analysis of the entire EU governance evolution that has been streamlined by the Lisbon-type reforms, a tendency confirmed by the new strategy. Indeed, Europe 2020 now holds a pivotal position in the entire EU policy-making because all major policies would have to incorporate its recommendations that represent the tenets of the EU's development in the upcoming period. These tenets are knowledge and innovation, competitiveness and green growth underpinned by social inclusion and higher levels of employment. This has particular importance for Croatia, as the future new EU member state, which should use the Europe 2020 strategy as leverage for reforms, thus paving the way for its efficient EU membership. In conclusion, the recommendations and evaluation of best practices in this book represent a valuable contribution on that path. The book is available for download at the IMO web-page: http://www.imo.hr/node/1231

Saša Čvrljak

\section{doi: $10.5559 /$ di.20.2.16 \\ Paul Belleflamme and Martin Peitz INDUSTRIAL ORGANIZATION Markets and Strategies}

Cambridge University Press, Cambridge (UK) 2010, 702 pp.

In the past two decades there has been a growing interest in industrial organization. Over the years, the study of industrial organization, as the analysis of imperfect markets and price theory, has evolved from an area in microeconomics to a self-defining part of economics strongly related to other 